\title{
PERUBAHAN STRUKTUR AGRARIA DAN IMPLIKASINYA TERHADAP GERAKAN PETANI PEDESAAN (Analisis Karakter Forum Paguyuban Petani Jasinga Pasca PPAN)
}

\author{
Agrarian Structure Change and Its Implications for Rural Farmers Movement \\ (Character Analysis Jasinga Farmers Association Forum Post PPAN)
}

\author{
Sari Lestari*) dan Heru Purwandari \\ Departemen Sains Komunikasi dan Pengembangan Masyarakat, Fakultas Ekologi Manusia, IPB
}

*Email: sarilestari3004@gmail.com

\begin{abstract}
Curug and Tegal Wangi community are facing the problem related to the land occupation. Two aspects which changed after the decrease of land occupation are the decrease of land tenure and income level. The emerging of Forum Paguyuban Petani Jasinga is a part of their strategy to over come the problem above. This study aims to analyze the influence of agrarian structure change to the character of organization. Result of this study shows there is no influence of change of social economic status to dimensions movement of farmers. On the other side, the dimensions of movement of farmers had influence in the character of movement farmers.
\end{abstract}

Keywords: agrarian structure change, peasant movement, paguyuban petani

\begin{abstract}
ABSTRAK
Masyarakat Curug dan Tegal Wangi memiliki masalah yang berkaitan dengan pendudukan lahan. Dua aspek yang berubah setelah penurunan pendudukan lahan adalah penurunan kepemilikan lahan dan tingkat pendapatan. Munculnya Forum Paguyuban Petani Jasinga merupakan bagian dari strategi mereka untuk menanggulangi masalah di atas. Penelitian ini bertujuan untuk menganalisis pengaruh agraria terhadap perubahan struktur karakter organisasi. Hasil penelitian menunjukkan tidak ada pengaruh perubahan status sosial ekonomi dengan dimensi gerakan petani. Di sisi lain, dimensi gerakan petani memiliki pengaruh dalam karakter petani gerakan.
\end{abstract}

Kata kunci: pergerakan petani, perubahan struktur agraria, petani paguyuban

\section{PENDAHULUAN}

Undang-Undang Pokok Agraria (UUPA) No. 5 Tahun 1960 mendefinisikan agraria sebagai seluruh bumi, air dan ruang angkasa, termasuk kekayaan alam yang terkandung didalamnya. Sumberdaya alam hakikatnya digunakan untuk kemakmuran rakyat sama seperti jaminan bahkan janji yang tertera dalam Undang-Undang Dasar. Namun, hal tersebut masih jauh dari kenyataan. Distribusi kepemilikan lahan yang timpang seolah menjadi pemandangan yang lazim. Tanah bukan hanya sebatas faktor produksi melainkan sebagai sumber penghidupan yang menyangkut hidup dan mati. Penguasaan tanah tidak hanya bermakna ekonomis dalam arti sebagai sumberdaya, tetapi kerap bermakna kultural, bahkan cenderung magis. Pandangan ini berkonotasi bahwa masalah pertanahan adalah masalah hubungan manusia dengan tanah.

Ketika sumberdaya alam seharusnya digunakan untuk kepentingan seluruh rakyat, hal yang berbeda ditemui di lapangan. Ketimpangan kepemilikan sumber agraria menjadi pemandangan lazim. Merujuk pada Wiradi (1999) ketimpangan kepemilikan sumber agraria dapat digolongkan ke dalam empat bentuk. Ketimpangan tersebut antara lain ketimpangan dalam hal penguasaan sumbersumber agraria, ketidakserasian dalam hal "peruntukan" sumber-sumber agraria, ketidakserasian antara persepsi dan konsepsi mengenai agraria, ketidakserasian antara berbagai produk hukum, sebagai akibat dari pragmantisme dan kebijakan sektoral. Respon yang dilakukan oleh pemerintah pusat yang bekerjasama dengan Badan Pertanahan Nasional (BPN) terkait ketimpangan kepemilikan lahan adalah dengan Program Pembaruan Agraria Nasional (PPAN). Kecamatan Jasinga merupakan daerah percontohan program tersebut untuk wilayah Jawa Barat. Upaya yang dilakukan dalam program ini adalah pemerintah memberikan tanah eks Hak Guna Usaha PT. PJ yang tidak diperpanjang pada seluruh masyarakat Desa Curug. Namun, rupanya hal bertolak belakang terjadi di lapangan. Hal ini dikarenakan, terdapat segelintir orang yang tidak mendapatkan bagian dari program tersebut. Pembagian tanah tersebut memang diperuntukan oleh para penggarap yang menggarap lahan eks perkebunan sejak tahun 2000. Segelintir orang yang tidak mendapatkan pembagian tanah tersebut padahal sedang terlilit konflik agraria dengan salah satu perusahaan yang sama-sama mengklaim kepemilikan tanah di bagian timur Kecamatan Jasinga. 
Konflik agraria yang terjadi antara petani dengan perusahaan terjadi pada awal tahun 2012. Konflik agraria tersebut menambah daftar kelam carut marut pertanahan nasional. Menurut data KPA (Konsorium Pembaruan Agraria) jumlah konflik agraria tahun 2011 mencapai 169 kasus. Konflik ini melibatkan 69975 kepala keluarga dengan luas areal konflik mencapai 472048.44 hektar. Dari 163 konflik agraria tahun 2011, rinciannya 97 kasus di sektor perkebunan, 36 kasus di sektor kehutanan, 21 kasus di sektor infrastruktur, delapan kasus di sektor pertambangan, dan satu kasus di wilayah tambak atau pesisir.

Hilangnya akses terhadap tanah yang dialami petani penggarap memicu terjadinya konflik agraria yang terjadi antara petani penggarap dengan pihak perusahaan. Konflik agraria yang terjadi di tahun 2012 antara pihak perkebunan dan petani penggarap secara langsung menyebabkan kerugian yang dialami oleh petani. Berangkat dari perubahan status sosial ekonomi yang dialami pasca kehilangan tanah garapan, memicu terpenuhinya dimensi gerakan petani. Terdapat empat dimensi gerakan petani yakni tingkat kesadaran, tingkat kolektifitas aksi, tingkat orientasi instrumental, dan status sosial. Dimensi gerakan petani dijadikan tolok ukur untuk melihat besar kepentingan seorang individu untuk tergabung dalam satu organisaasi gerakan petani. Berangkat dari kerugian yang dialami oleh mantan penggarap menyebabkan terbentuknya embrio gerakan petani yang terjadi di Desa Curug dan Desa Tegal Wangi, Kecamatan Jasinga. Gerakan petani terorganisir ketika terjadinya tumpang tindih kepemilikan lahan. Masyarakat mengklaim bahwa tanah tersebut adalah tanah yang sudah digarap secara turun temurun. Namun dilain sisi, pihak perkebunan menganggap tanah tersebut masih bagian dari HGU perusahaan tersebut. Kondisi tersebut mendorong petani untuk membentuk Forum Paguyuban Petani Jasinga untuk mempertahankan lahan milik mereka. Landsberger dan Alexandrov (1974) mengatakan gerakan petani adalah rekasi kolektif terhadap kedudukan rendah petani itu sendiri. Gerakan petani muncul sebagai reaksi terhadap tindakan eksplorasi, ekstraksi, dan ekspoitasi.

Reaksi petani memang tidak selalu langsung melawan. Ada pula gerakan yang menghindari tekanan-tekanan dari atas dengan lari menjauhkan diri dari pusat kekuasaan dan penghisapan. Sifat gerakan setiap masanya memiliki corak khas tertentu. Gerakan yang terjadi dapat berbentuk radikal ataupun berbentuk halus seperti penghindaran. Gerakan yang dilakukan petani semata-mata untuk menuntut haknya kembali ataupun menuntut keadilan sosial. Penelitian Purwandari (2006) membahas mengenai bentuk gerakan yang lebih "halus" dengan mengedepankan kemandirian kelompok SPPQT.

Hal ini terjadi ketika ketergantungan dan kebijakan yang merugikan petani terus dilakukan oleh pemerintah menyebabkan kelompok ini berontak dan melawannya dengan menciptakan kemandirian kelompok. Potret keberhasilan ditunjukkan oleh kelompok perjuangan dua petani Jenggawah, Jember, Jawa Timur yang berhasil mendapatkan tanah mereka kembali pada era Orde Baru. Lain halnya dengan gerakan petani di Lampung yang mengalami stagnansi akibat disorientasi para aktor dalam tubuh organisasi Serikat Petani Lampung. Lebih lanjut, Hartoyo (2010) involusi gerakan agraria terjadi ketika struktur sumberdaya mobilisasi melemah (deformasi, decoupling dan stagnansi) dan sifat struktural organisasi gerakan semakin melekat pada sistem agraria yang mapan sedangkan program perjuangan belum terlembagakan.

Organisasi gerakan petani dijadikan alat untuk memperjuangkan kembali hak-hak mereka yang hilang. Hartoyo (2010) menjelaskan peran organisasi gerakan petani sebagai alat untuk tercapainya transformasi agraria. Stagnansi gerakan petani terjadi karena dalam proses penguatan struk tur mobilisasi sumberdaya diwarnai disorientasi perilaku para elit aktor yang konsekuensinya tidak dapat diprediksi dan dikontrol.

Ketika akses atas tanah hilang akibat konfilk agraria yang terjadi, gerakan petani menjadi wujud reaksi terhadap kemerosotan status sosial ekonomi yang dialami oleh petani. Organisasi gerakan petani dibentuk dengan harapan untuk memperjuangkan sumber-sumber agraria yang masih dipertanyakan kepemilikannya. Namun, kenyataan yang terjadi menunjukkan terjadinya stagnansi pergerakan petani dalam Forum Paguyuban Petani Jasinga. Maka penting untuk melihat pengaruh perubahan status sosial ekonomi terhadap karakter gerakan petani pedesaan terkait hubungannya dengan terpenuhinya dimensi-dimensi gerakan petani.

Oleh karena itu, penelitian ini mengkaji tentang: 1) Bagaimana perubahan status sosial ekonomi setelah perpanjangan Hak Guna Usaha (HGU)? 2) Bagaimana pengaruh perubahan status sosial ekonomi terhadap terpenuhinya dimensi-dimensi gerakan petani pedesaan? 3 ) Bagaimana pengaruh terpenuhi dimensi-dimensi gerakan petani terhadap karakter gerakan petani pedesaan?

\section{PENDEKATAN TEORITIS}

\section{Tinjauan Pustaka}

\section{Srtuktur agraria}

Struktur agraria menurut Wiradi (2009) merujuk kepada susunan sebaran atau distribusi tentang pemilikan (penguasaan formal) dan penguasaan efektif (garapan/ operasional) atas sumber-sumber agraria, juga sebaran alokasi dan peruntukannya. Struktur agraria bukan hanya sebatas menyangkut hubungan teknis antara manusia atau subjek dengan tanahnya atau objek, melainkan juga menyangkut hubungan sosial manusia dengan manusia. Hal ini berarti mencakup hubungan orang-orang yang langsung atau tidak langsung terlibat dalam proses produksi.

Zuber (2007) mengemukakan ada empat faktor yang mempengaruhi perubahan struktur agraria, diantaranya: permintaan lahan dari kegiatan non-pertanian seperti pembangunan real estate, pabrik, areal perdagangan dan pelayanan lainnya yang membutuhkan areal tanah yang luas; faktor sosial budaya, seperti adanya aturan warisan; kerusakan lingkungan seperti adanya musim kemarau panjang yang mengakibatkan kekeringan terutama pada usaha pertanian; penggunaan pestisida ataupun pupuk yang dapat mematikan predator dan kerusakan lahan pertanian; dan kelemahan hukum yang mengatur bidang pertanian, seperti harga pupuk yang tinggi, harga gabah yang rendah dan masalah pengaturan harga beras yang sampai sekarang masih sangat pelik.

\section{Kondisi Sosial Ekonomi}

Kondisi sosial ekonomi dapat diartikan sebagai posisi 
individu dan kelompok yang berkenaan dengan ukuran rata-rata yang berlalu umum tentang pendidikan, pemilikan barang, dan partisipasi dalam aktivitas kelompok dari komunitasnya (Basrowi dan Juariyah, 2010). Lebih lanjut, penelitian (Basrowi dan Juariyah, 2010) menggunakan luas lahan garapan dan pekerjaan yang sedang dijalani sebagai indikator untuk mengukur status sosial ekonomi masyarakat Desa Srigading, Lampung Timur yang mayoritas penduduknya adalah petani. Kondisi sosial ekonomi adalah keadaan seseorang atau sekelompok orang yang dapat dilihat dari faktor pendidikan, status pekerjaan, tingkat pendapatan, kekayaan, kepemilikan barang berharga serta kedudukan di tengah masyarakat.

\section{Gerakan Petani}

Landsberger dan Alexandrov (1974) mendefinisikan gerakan petani sebagai reaksi kolektif terhadap kedudukan rendah petani. Sejalan dengan yang dikemukan oleh Hartoyo (2010) gerakan petani adalah gerakan sosial terdiri atas aktor petani dan non petani yang membingkai isu atau mengusung agenda perubahan tatanan agraria dan basis masa utamanya adalah petani. Berangkat dari definisi tentang gerakan petani di atas, dapat disarikan bahwa gerakan petani adalah reaksi kolektif yang dilakukan oleh petani dengan tujuan untuk melakukan perubahan tatanan agararia yang selama ini dinilai merugikan petani yang diwadahi oleh sebuah organisasi petani. Scott dan Popkin dalam Firmansyah (1999) mengatakan bahwa terdapat empat faktor yang menimbulkan kemarahan kaum tani pedesaan di masa kolonial, yaitu perubahan struktur agraria, meningkatnya eksploitasi, kemerosotan status sosial, dan deprivasi relatif.

Sudut pandang lain yang digunakan untuk menganalisis secara lebih mendalam pada konsep gerakan petani adalah dengan menganalisis dimensi gerakan petani. Dimensi gerakan petani terdiri dari empat dimensi yaitu tingkat kesadaran, tingkat kolektifitas aksi, tingkat orientasi intrumental, dan status rendah. Kesadaran merupakan titik awal dari kesamaan objektif dari keadaan objektif, dan pemiskinan yang bisa diharapkan dari kompetisi kapitalis dan krisis yang makin dalam. Kolektifitas aksi adalah dimana petani saling tergabung dalam kebersamaan untuk mencapai tujuan yang mereka inginkan. Puncak dari dimensi ini adalah lahirnya koordinasi pembagian tugas dan kerja serta wewenang. Ketiga ialah perilaku orientasi instrumental yang merupakan kata sifat yang diletakan bila suatu perkumpulan atau gerakan mengejar sasaran yang terletak di luar kegiatan langsung mereka. Status rendah sebagai basis gerakan merupakan dimensi keempat dari gerakan petani. Status rendah yang dialamatkan pada petani menjadi gaya dorong dalam melakukan gerakan. Perubahan yang dituntut merupakan cara untuk menyamakan kedudukan petani dengan aktor lainnya.

\section{Hipotesis Penelitian}

Hipotesis penelitian ini disajikan sebagai berikut:

1. Diduga, perubahan status sosial ekonomi ekonomi berpengaruh terhadap terpenuhinya dimensi-dimensi gerakan petani

2. Diduga, terpenuhinya dimensi gerakan petani berpengaruh terhadap karakter gerakan petani

\section{Kerangka Pemikiran}

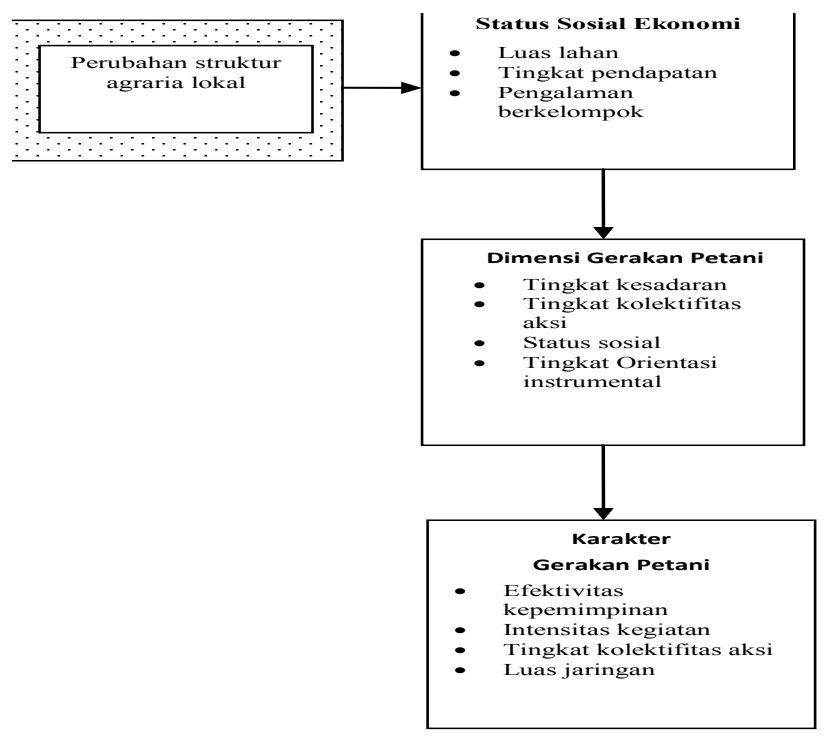

Keterangan:

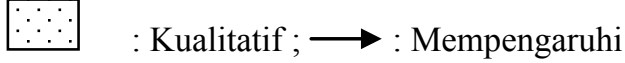

\section{PENDEKATAN LAPANG}

Pendekatan penelitian yang digunakan pada penelitian ini adalah pendekatan penelitian kuantitatif yang didukung oleh data kualitatif untuk menjelaskan kondisi di lapangan saat pengambilan data berlangsung. Instrumen yang digunakan dalam pendekatan kuantitatif adalah kuesioner. Lokasi penelitian dilakukan di organisasi Forum Paguyuban Petani Jasinga yang sebaran anggotanya di Desa Curug dan Desa Tegal Wangi. Populasi dari penelitian ini adalah seluruh petani yang tergabung dalam Forum Paguyuban Petani Jasinga. Unit analisis dalam penelitian ini adalah individu. Sebaran anggota organisasi ada di dua desa yakni Desa Curug dan Desa Tegal Wangi. Teknik penentuan responden dilakukan dengan teknik snow ball. Merujuk pada Rianse dan Abdi (2009) teknik snow ball merupakan teknik sampling yang dicirikan dengan tidak tersedianya data jumlah populasi, sehingga tidak dimungkinkan untuk membuat kerangka sampling. Teknik pengolahan data dilakukan dengan SPSS for windows 20 dengan uji regresi dan uji t-test paired.

\section{PROFIL LOKASI PENELITIAN}

\section{Forum Paguyuban Petani Jasinga}

Forum Paguyuban Petani Jasinga dibentuk sebagai respon atas perubahan akses yang dialami masyarakat di Desa Curug, Desa Tegal Wangi, dan Desa Wirajaya. Perubahan akses terhadap lahan garapan yang terjadi pada tahun 2008 disebabkan oleh diperpanjangnya Hak Guna Usaha tanah eks PT. PJ oleh perusahaan lain. Tahun 2012, merupakan tahun dimana lahirnya Forum Paguyuban Petani Jasinga. Organisasi ini merupakan basis bagi para mantan penggarap untuk menuntut hak garap kembali atas tanah yang sejak tahun 1998 digarap oleh mereka. Secara struktur, belum bisa dipetakan siapa saja yang menjadi anggota dalam organisasi ini. Sejak pembentukannya tahun 2012 silam, organisasi ini baru memiliki ketua paguyuban 
yang pemilihannya dilakukan berdasarkan instruksi dari ketua Ormas yang membantu dalam proses penyelesaian sengketa lahan garapan. Sebelum terbentuknya suatu organisasi, pada tahun 2008 hingga tahun 2012, mantan penggarap sudah melakukan aktivitas kebersamaan seperti kasus penyelesaian hukum yang membelit beberapa mantan penggarap. Kasus hukum tersebut dilaporkan oleh pihak perusahaan kepada pihak kepolisian atas tuduhan pengrusakan.

\section{Desa Cakupan Organisasi}

\section{Desa Curug}

Desa Curug merupakan salah satu desa yang terletak di Kecamatan Jasinga, Kabupaten Bogor, Jawa Barat. Desa Curug secara administratif terbagi menjadi lima kampung, yakni Kampung Ngasuh, Kampung Barangbang, Kampung Liud, Kampung Curug, dan Kampung Baru. Kampung Barambang yang awalnya menjadi bagian dari Desa Curug, mengalami pemekaran menjadi Desa Wirajaya pada tahun 2009. Desa Curug berbatasan langsung dengan Desa Wirajaya sebelah barat dan selatan, Desa Jugalaya sebelah timur, dan Desa Koleang sebelah utara. Wilayah Desa Curug merupakan wilayah yang dikelilingi oleh perkebunan, baik perkebunan rakyat maupun yang dikelola oleh pemerintah atau swasta. Kondisi geografis ini berpengaruh terhadap mata pencaharian penduduk yang bekerja sebagai petani. Pertanian yang dilakukan oleh penduduk Desa Curug adalah pertanian tanaman kebun.

\section{Desa Tegal Wangi}

Desa Tegal Wangi merupakan desa pemekaran dari Desa Koleang yang berbatasan langsung di sebelah timur. Pemekaran dari Desa Koleang terjadi pada tahun 1987. Desa Tegal Wangi berbatasan langsung dengan Desa Candi di sebelah utara, Desa Koleang di sebelah timur, Desa Curug di sebelah selatan, dan Desa Lebak Asih di sebelah barat. Mata pencaharian yang digeluti oleh mayoritas masyarakat Desa Tegal Wangi adalah petani dengan jumlah 860 jiwa. Selain itu, buruh tani di Desa Tegal Wangi tercatat ada 612 jiwa. Sektor pertanian padi sawah dan perkebunan karet menjadi andalan bagi masyarakat Desa Tegal Wangi. Namun, tercatat 1800 jiwa yang tidak bekerja.

Sistem pertanian yang digunakan oleh masyarakat Desa Tegal Wangi adalah sistem pertanian tradisional. Hal ini dikarenakan, hasil panen yang didapat bukan untuk dijual melainkan untuk konsumsi umah tangga. Untuk memenuhi kebutuhan seahari-hari, masyarakat Desa Tegal Wangi bekerja sebagai buruh sadap karet dengan sistem bagi hasil atau maparo.

\section{PERUBAHAN STATUS SOSIAL EKONOMI PASCA PERPANJANGAN HGU}

\section{Perubahan Struktur Agraria Lokal}

Lahan eks Hak Guna Usaha PT. PJ yang luasnya mencapai 2000 hektar di Kecamatan Jasinga dimanfaatkan oleh masyarakat di Desa Curug dan Desa Tegal Wangi sebagai lahan garapan. Penggarapan lahan tersebut dimulai sejak tahun 1998. Pada tahun 2008 Hak Guna Usaha lahan eks PT. PJ diperpanjang oleh sebuah perusahaan yang tidak diketahui identitasnya oleh masyarakat sekitar. Tidak semua lahan eks Hak Guna Usaha PT. PJ diperpanjang.
Luasan lahan yang termasuk ke dalam zona perpanjangan Hak Guna Usaha seluas 938 hektar. Sisa lahan yang tidak termasuk ke dalam perpanjangan Hak Guna Usaha atau 1 200 hektar, diberikan kepada masyarakat pada Program Pembaruan Agraria Nasional.

Tahun 2008 pun bertepatan dengan pelaksanaan Program Pembaruan Agraria Nasional (PPAN) di Kecamatan Jasinga. Blok Ciohol merupakan zona dari pembagian lahan dari Program Pembaruan Agraria Nasional. Blok yang termasuk ke dalam zona perpanjangan Hak Guna Usaha Jilid dua adalah Blok Cikidung. Luasan lahan yang termasuk ke dalam perpanjangan Hak Guna Usaha adalah 928 hektar sedangkan luasan lahan yang termasuk ke dalam zona pembagian lahan pada Program Pembaruan Agraria Nasional adalah 1200 hektar.

Perubahan akses terhadap lahan garapan dialami masyarakat di Desa Curug dan Desa Tegal Wangi yang sejak awal menggarap lahan di Blok Cikidung. Menurut penuturan salah satu responden, pelaksanaan Program Pembaruan Agraria Nasional tidak memberikan dampak positif bagi semua masyarakat di Desa Curug dan Desa Tegal Wangi. Hal ini dikarenakan tidak semua masyarakat mendapat pembagian lahan dari program tersebut dan kehilangan lahan garapan saat perpanjangan Hak Guna Usaha.

\section{Perubahan Luas Penguasan Lahan}

Luas penguasaan lahan yang dimaksud adalah total luas seluruh lahan yang dikuasai oleh responden baik itu milik, garap, bagi hasil, dan sewa. Lahan eks Hak Guna Usaha yang dimanfaatkan oleh para penggarap sebagai sumber penghidupan keluarga.

\section{Tabel 1 Persentase Responden Berdasarkan Luas} Penguasaan Lahan

\begin{tabular}{llll}
\hline $\begin{array}{l}\text { Luas penguasaan la- } \\
\text { han }\end{array}$ & Rendah (\%) & Tinggi (\%) & Total (\%) \\
\hline $\begin{array}{l}\text { Sebelum perpanjan- } \\
\text { gan HGU }\end{array}$ & 52 & 100 \\
$\begin{array}{l}\text { Setelah perpanjan- } 90 \\
\text { gan HGU }\end{array}$ & 10 & 100 \\
\hline
\end{tabular}

Hilangnya akses terhadap lahan garapan menyebabkan perubahan luas penguasaan lahan. Responden yang menguasai lahan rendah bertambah setelah perpanjangan Hak Guna Usaha sedangkan responden yang menguasai lahan tinggi berkurang. Pasca perpanjangan Hak Guna Usaha, responden terkonsentrasi pada luas penguasaan lahan rendah. Responden yang pada awalnya tergolong pada luas penguasaan lahan tinggi mengalami perubahan ke dalam golongan luas penguasaan lahan rendah. Hal ini disebabkan oleh perubahan akses yang dialami oleh responden.

Hanya 10 persen responden yang masih tergolong ke dalam luas penguasaan lahan tinggi. Hal ini dikarenakan sebagian kecil responden ini masih menguasai lahan secara fisik. Lebih jauh pasca penebangan paksa oleh pihak perusahaan, ada beberapa responden yang berdomisili di Desa Curug masih menguasai secara fisik lahan tersebut. Berbeda dengan yang terjadi di Desa Tegal Wangi. Tercatat delapan responden yang pada akhirnya memiliki lahan 
garapan secara legal. Hal ini dikarenakan lokasi lahan garapan mereka dahulu termasuk ke dalam zona Program Pembaruan Agraria Nasional.

Perbedaan kondisi terlihat dari perubahan luas penguasaan lahan yang dikuasai oleh responden. Berdasarkan Uji t-test paired terjadi penurunan mean dari 1.04 menjadi 0.2 . Selain itu, nilai sig yang didapatkan adalah 0,023 . Nilai t hitung yang didapat adalah 5.975. Berdasarkan hasil uji beda tersebut, dapat diartikan bahwa terjadi perbedaan antara sebelum dan setelah perpanjangan. Hal ini dibuktikan oleh nilai $\mathrm{t}$ hitung yang lebih besar $(>)$ dari $\mathrm{t}$ tabel. $\mathrm{T}$ hitung bernilai 5.975 sedangkan $t$ tabel bernilai 1.676. Mean hasil uji beda menunjukkan penurunan dari 1.04 menjadi 0.2 . Hal tersebut didukung dengan fakta di lapangan yang menunjukkan luas penguasaan lahan setelah perpanjangan Hak Guna Usaha menurun dan responden terkonsentrasi pada luas penguasaan lahan rendah.

\section{Perubahan Tingkat Pendapatan}

Perubahan pendapatan dirasakan ketika hilangnya akses terhadap lahan garapan di eks Hak Guna Usaha. Walaupun tanah yang responden kuasai bukan hanya tanah eks Hak Guna Usaha tersebut, responden menjadikan pendapatan dari sadapan karet sebagai pendapatan harian yang biasa digunakan untuk kebutuhan rumah tangga sehari-hari.

Tabel 2 Persentase Responden Berdasarkan Tingkat Pendapatan

\begin{tabular}{llll}
\hline Tingkat pendapatan & $\begin{array}{l}\text { R e n d a h } \\
(\%)\end{array}$ & $\begin{array}{l}\text { T i n g g i } \\
(\%)\end{array}$ & $\begin{array}{l}\text { To t a l } \\
(\%)\end{array}$ \\
\hline $\begin{array}{l}\text { Sebelum perpanjan- } \\
\text { gan HGU }\end{array}$ & 58 & 42 & 100 \\
$\begin{array}{l}\text { Setelah perpanjangan } \\
\text { HGU }\end{array}$ & 86 & 14 & 100 \\
\hline
\end{tabular}

Hilangnya lahan garapan berpengaruh terhadap pendapatan responden. Penurunan pendapatan akibat tidak adanya lagi hasil sadapan karet menyebabkan penambahan jumlah responden yang memiliki tingkat pendapatan rendah. Jumlah responden yang memiliki tingkat pendapatan tinggi pun berubah pasca perpanjangan Hak Guna Usaha. Responden yang memiliki tingkat pendapatan tinggi setelah perpanjangan $\mathrm{HGU}$ adalah responden yang memiliki usaha di sektor non pertanian yang memiliki omzet yang besar. Dampak lanjutan yang terjadi dari perubahan tingkat pendapatan pasca hilangnya lahan garapan adalah terdapat beberapa anak responden atau anggota keluarganya yang mengalami putus sekolah. Keterbatasan pendapatan setiap bulannya berdampak pada tidak dilanjutkannya jenjang pendidikan anak atau anggota keluarga responden.

Uji t-test paired digunakan untuk melihat perbedaan tingkat pendapatan sebelum dan setelah perpanjangan Hak Guna Usaha. Hasil yang didapatkan menunjukkan penurunan mean dari 0.6 menjadi 0.24 . Selain itu, nilai sig yang didapat adalah 0.037. T hitung yang didapat dari uji beda ini adalah 2.641. Berdasarkan hasil uji beda tersebut dapat diartikan bahwa tingkat pendapatan sebelum perpanjangan Hak Guna Usaha dan setelah perpanjangan Hak Guna Usaha berbeda. Hal tersebut dibuktikan dengan nilai thitung yang lebih besar $(>)$ dari t tabel. Thitung yang didapat bernilai 2.641 sedangkan $t$ tabel bernilai 1.676 .

\section{Pengalaman Berkelompok}

Anggota yang tergabung dalam Forum Paguyuban Petani Jasinga adalah elemen masyarakat yang tidak dilibatkan dalam proses perjuangan Program Pembaruan Agraria Nasional. Lebih jauh, anggota yang tergabung dalam Forum Paguyuban Petani Jasinga adalah masyarakat yang tidak mendapatkan pembagian tanah dari Program Pembaruan Agraria Nasional. Namun, hal tersebut tidak untuk seluruh responden. Hal ini dikarenakan, terdapat delapan responden yang berdomisili di Desa Tegal Wangi yang menerima pembagian lahan dari Program Pembaruan Agraria Nasional.

Tabel 3 Jumlah dan Persentase Responden Berdasarkan Pengalaman Berkelompok

\begin{tabular}{lll}
\hline $\begin{array}{l}\text { Pengalaman berkelom- } \\
\text { pok }\end{array}$ & $\begin{array}{l}\text { J u m l a } \\
\text { (orang) }\end{array}$ & $\begin{array}{l}\text { Persentase } \\
(\%)\end{array}$ \\
\hline Rendah & 43 & 86 \\
Tinggi & 7 & 14 \\
Total & 50 & 100 \\
\hline
\end{tabular}

Terkonsentrasinya responden pada golongan ini dikarenakan oganisasi Forum Paguyuban Petani Jasinga merupakan organisasi pertama yang diikuti. Kondisi di lapangan menunjukkan bahwa pengalaman berkelompok yang rendah menjadi gaya dorong untuk terlibat dalam organisasi. Ketika ada satu organisasi yang dibentuk berdasarkan keinginan masyarakat dan berangkat dari latar belakang kondisi marjinal. Kesempatan untuk berkelompok dimanfaatkan dengan baik terlebih kelompok yang dibentuk memiliki tujuan untuk memperjuangkan tanah garapan mereka. Selain itu, anggota paguyuban di Desa Curug menyadari bahwa mereka merupakan bagian dari kelompok. Berbeda dengan anggota paguyuban di Desa Tegal Wangi yang tidak menyadari keterlibatan dalam organisasi. Hanya responden yang berperan sebagai penggagas yang menyadari keterlibatan dalam organisasi.

\section{DIMENSI GERAKAN PETANI}

\section{Status Sosial}

Tabel 4 Jumlah dan Persentase Responden Berdasarkan Status Sosial

\begin{tabular}{lll}
\hline Status sosial & Jumlah (orang) & Persentase (\%) \\
\hline Rendah & 33 & 66 \\
Tinggi & 17 & 34 \\
\hline Total & 50 & 100 \\
\hline
\end{tabular}

Responden yang memiliki status sosial tinggi adalah anggota paguyuban yang diundang rapat untuk membicarakan ganti rugi tanaman yang mereka tanam di atas lahan eks Hak Guna Usaha PT PJ. Banyak responden yang diundang namun tidak menghadiri rapat pertemuan tersebut. Ketidakhadiran dalam rapat tersebut sebagai wujud penolakan atas penebangan paksa yang dilakukan pihak perusahaan. Rapat desa yang mengundang responden tersebut karena berkaitan dengan lahan garapan yang digarap oleh responden. Selain perihal ganti rugi tanaman milik responden, rapat desa biasanya diadakan 
hanya untuk para elit desa dan tokoh. Jadi, masyarakat biasa tidak diundang dalam rapat desa. Seperti yang diungkapkan oleh salah satu responden, berangkat dari status sosial yang disandang oleh setiap responden, maka timbul satu keinginan untuk memperbaiki status sosial mereka kini. Status sosial menjadi pijakan pertama dalam proses pembentukan gerakan petani. Keinginan untuk menyamakan posisi dengan aktor atau pihak lain menjadi titik awal untuk memperjuangkan hal tersebut.

\section{Tingkat Kesadaran}

Tabel 5 Jumlah dan Persentase Responden Berdasarkan Tingkat Kesadaran

\begin{tabular}{|c|c|c|}
\hline Tingkat kesadaran & $\begin{array}{l}\mathrm{J} \\
\text { (orang) } \\
\end{array}$ & Persentase (\%) \\
\hline Rendah & 3 & 6 \\
\hline Sedang & 16 & 32 \\
\hline Tinggi & 31 & 62 \\
\hline Total & 50 & 100 \\
\hline
\end{tabular}

Sebagian besar anggota paguyuban memiliki tingkat kesadaran tinggi karena mereka menyadari bahwa kerugian akibat kehilangan aksesnya tersebut menyebabkan perubahan status sosial ekonomi yang mereka alami kini. Hal yang sama juga terjadi pada responden di Desa Tegal Wangi. Responden yang bermukim di Desa Tegal Wangi, menyadari bahwa pihak perusahaan yang didampingi jawara menjadi musuh bersama mereka dan menjadi titik awal perubahan akses yang mereka alami kini. Lebih jauh, keinginan yang mendorong untuk terlibat dalam kegiatan organisasi tidak hanya karena keinginan sendiri melainkan karena diajak oleh penggarap lain atau rasa empati yang ditimbul ketika melihat kondisi tetangga yang terpuruk pasca kehilangan akses garapan. Tidak semua yang ikut dalam kegiatan organisasi adalah mantan penggarap yang kehilangan akses pasca perpanjangan Hak Guna Usaha, melainkan ada beberapa responden yang tidak kehilangan akses garapan karena tanah garapannya terdahulu termasuk ke dalam zona Program Pembaruan Agraria Nasional, yang ikut dalam kegiatan ini seperti ungkapan salah satu responden di Tegal Wangi.

\section{Tingkat Kolektifitas}

Tabel 6 Jumlah dan Persentase Responden Berdasarkan Tingkat Kolektifitas

\begin{tabular}{lll}
\hline Tingkat kolektifitas & $\begin{array}{l}\text { J u m l a h } \\
\text { (orang) }\end{array}$ & $\begin{array}{l}\text { Persentase } \\
(\%)\end{array}$ \\
\hline Rendah & 9 & 18 \\
Sedang & 28 & 56 \\
Tinggi & 13 & 26 \\
Total & 50 & 100 \\
\hline
\end{tabular}

Hal yang menjadi penentu dalam tingkat kolektifitas adalah adanya figur yang mampu merangkul para penggarap untuk bersatu atau berperan sebagai penggagas. Lebih jauh, hasil penelitian di lapangan menunjukkan bahwa tidak semua responden mengikuti proses pembentukan organisasi petani walaupun mereka mengalami perubahan luas penguasaan lahan. Posisi mereka hanya sebatas anggota bukan penggagas. Hal tersebut juga memperlihatkan keikutsertaan responden dalam tahap persiapan pembentukan organisasi seperti rapat dan diskusi. Singkatnya, banyak responden yang tidak mengikuti proses awal pembentukan organisasi.

Bantuan yang diberikan oleh responden dalam tahap pembentukan organisasi masih minim. Hal ini dikarenakan, anggota paguyuban di Desa Tegal Wangi tidak mengetahui tentang proses pembentukan dan asal muasal organisasi Forum Paguyuban Petani Jasinga. Hanya beberapa dari responden saja yang mengetahui dengan jelas perihal tersebut karena mereka dianggap penggagas di Desa Tegal Wangi sedangkan responden lainnya tidak mengetahui. Saat penentuan responden pun, peneliti bertolak dari mantan penggarap yang minimal pernah mengikuti kegiatan bersama dengan mantan penggarap dari Desa Curug. Bisa dikatakan, reponden lainnya hanya sebatas anggota tanpa menyadari bahwa responden tersebut terlibat dan menjadi bagian dari organisasi tersebut.

\section{Tingkat Orientasi Instrumental}

Tabel 7 Jumlah dan Persentase Responden Berdasarkan Tingkat Orientasi Instrumental

\begin{tabular}{lll}
\hline $\begin{array}{l}\text { Tingkat orientasi instru- } \\
\text { mental }\end{array}$ & $\begin{array}{l}\text { J u m l a h } \\
\text { (orang) }\end{array}$ & $\begin{array}{l}\text { Persentase } \\
(\%)\end{array}$ \\
\hline Rendah & 5 & 10 \\
Sedang & 30 & 60 \\
Tinggi & 15 & 30 \\
Total & 50 & 100 \\
\hline
\end{tabular}

Orientasi instrumental diartikan sebagai tujuan seseorang untuk tergabung dalam suatu gerakan petani dan apa yang ingin dicapai. Berangkat dari kondisi responden yang berbeda, tujuan dalam mengikuti gerakan petani pun berbeda. Bagi para responden yang akses tanah garapannya hilang tujuan mengikuti pergerakan petani adalah untuk memperjuangkan akses atas tanah garapan kembali.

Terkonsentrasinya responden pada tingkat orientasi instrumental sedang dikarenakan keyakinan mereka yang rendah atas keberhasilan organisasi ini. Hal ini dikarenakan, sudah hampir enam tahun pasca penebangan paksa dan dua tahun pembentukan organisasi belum membuahkan hasil yang sesuai. Keyakinan anggota paguyuban terhadap keberhasilan organisasi masih rendah. Kisaran keyakinan mereka hanya 50 persen atas keberhasilan organisasi ini. Hal ini dikarenakan, sudah bertahun-tahun diupayakan namun belum membuahkan hasil. Banyak cara yang dilakukan oleh responden di kedua desa untuk memperjuangkan kembali akses untuk menggarap. Responden di Desa Curug mencoba mengadukan pada pihak desa atas peristiwa pengrusakan dan penebangan paksa tanaman mereka. Namun, hasilnya nihil. Masyarakat tidak ditanggapi dan merasa tidak dilindungi.

\section{Tingkat Terpenuhinya Dimensi Gerakan Petani}

Hasil pengamatan di lapangan hal yang menyebabkan terkonsentrasinya tingkat terpenuhi dimensi gerakan petani pada level sedang dikarenakan perbedaan komposisi dari sub variabel dimensi gerakan petani. Tidak semua 
responden menganggap bahwa petani atau penggarap yang menguasai tanah ada pada tingkat tertinggi. Selain itu, tidak semua responden memiliki latar belakang yang sama, yakni kerugian akibat kehilangan akses atas lahan garapan. Perubahan pekerjaan yang dialami pasca kehilangan lahan garapan menjadi tuntutan tersendiri bagi reponden untuk tidak dapat mengikuti kegiatan organisasi atau bersama. Berangkat dari kondisi yang berbeda, motif yang ada dari responden pun berbeda.

Tabel 8 Jumlah dan Persentase Responden Berdasarkan Tingkat Terpenuhinya Dimensi Gerakan Petani

\begin{tabular}{lll}
\hline $\begin{array}{l}\text { Tingkat terpenuhinya dimen- } \\
\text { si gerakan petani }\end{array}$ & $\begin{array}{l}\mathrm{J} \mathrm{u} \mathrm{m} \mathrm{l} \mathrm{a} \mathrm{h} \\
\text { (orang) }\end{array}$ & $\begin{array}{l}\text { Persentase } \\
\text { (\%) }\end{array}$ \\
\hline Rendah & 8 & 16 \\
Sedang & 31 & 62 \\
Tinggi & 11 & 22 \\
Total & 50 & 100 \\
\hline
\end{tabular}

Anggota paguyuban yang memiliki tingkat terpenuhinya dimensi rendah adalah anggota yang keikutsertaannya hanya sebatas tergabung. Berbeda dengan responden yang memiliki tingkat dimensi gerakan petani sedang. Anggota paguyuban yang ada pada kategori ini adalah anggota yang keikutsertaannya dalam organisasi berdasarkan kesadaran sendiri tetapi tidak mengikuti kegiatan awal pembentukan organisasi. Responden yang memiliki tingkat terpenuhinya dimensi gerakan petani tinggi adalah anggota paguyuban yang perannya dalam pembentukan organisasi sebagai penggagas.

Pengaruh Perubahan Status Sosial Ekonomi terhadap Tingkat Terpenuhinya Dimensi Gerakan Petani

Tabel 9 Hasil Uji Pengaruh Variabel Perubahan Status Sosial Ekonomi terhadap Tingkat Terpenuhinya Dimensi Gerakan Petani

\begin{tabular}{lll}
\hline Variabel & $\begin{array}{l}\mathrm{T} \\
\text { hitung }\end{array}$ & sig \\
\hline Luas penguasaan lahan & 1.715 & 0.093 \\
Tingkat pendapatan & -0327 & 0.745 \\
Pengalaman berkelompok & -0.295 & 0.769 \\
\hline
\end{tabular}

Berdasarkan uji statistik, variabel luas penguasaan lahan memberikan pengaruh terhadap tingkat terpenuhinya dimensi gerakan petani. Kondisi di lapangan menunjukkan bahwa kerugian akibat kehilangan lahan mendorong untuk mengorganisir diri dalam organisasi tani. Hal ini dikarenakan, kondisi yang berbeda jelas terlihat antara sebelum dan setelah perpanjangan Hak Guna Usaha. Walaupun tidak semua anggota paguyuban mengalami kehilangan akses atas lahan, hal tersebutlah yang diusung oleh organisasi ini, yakni memperjuangkan akses atas lahan garapan yang hilang.

Berdasarkan uji statistik, variabel tingkat pendapatan tidak memiliki pengaruh terhadap tingkat terpenuhinya dimensi gerakan petani. Hal tersebut disebabkan oleh sadapan karet yang menjadi tumpuan hidup anggota paguyuban hilang akibat hilangnya lahan garapan. Namun, setelah perpanjangan Hak Guna Usaha, ada beberapa responden yang tidak mengalami penurunan tingkat pendapatan. Hal ini dikarenakan, sumbangsih dari sektor non-pertanian lebih besar dari sektor pertanian.

Berdasarkan hasil uji statistik pengalaman organisasi rendah yang dimiliki oleh anggota paguyuban tidak memiliki pengaruh terhadap tingkat terpenuhinya dimensi gerakan petani. Hasil penelitian di lapangan menunjukkan minimnya kontribusi yang diberikan oleh anggota paguyuban. Hal tersebut disebabkan oleh keikutsertaan anggota dalam organisasi merupakan pengalaman pertama sehingga anggota paguyuban belum paham tahapan dalam pembentukan organisasi. Namun, disisi lain dengan pengalaman oganisasi yang rendah hal tersebut menjadi faktor pendorong anggota paguyuban mau terlibat dalam organisasi.

\section{KARAKTER GERAKAN PETANI}

\section{Efektivitas Kepemimpinan}

Tabel 10 Jumlah dan Persentase Responden Berdasarkan Efektivitas Kepemimpinan

\begin{tabular}{|c|c|c|c|}
\hline $\begin{array}{l}\text { Efektivitas } \\
\text { mpinan }\end{array}$ & kepemi- & $\begin{array}{l}\mathrm{J} \text { u } \mathrm{m} 1 \mathrm{a} \mathrm{h} \\
\text { (orang) }\end{array}$ & $\begin{array}{l}\text { Persentase } \\
(\%)\end{array}$ \\
\hline Rendah & & 11 & 22 \\
\hline Sedang & & 20 & 40 \\
\hline Tinggi & & 19 & 38 \\
\hline Total & & 50 & 100 \\
\hline
\end{tabular}

Lebih jauh, dua kondisi yang berbeda ditunjukkan dari penelitian didua desa tersebut. Sosok ketuayang berdomosili di Desa Curug, memperlihatkan kedekatan ketua dengan anggota di Desa Curug lebih baik dibandingkan di Desa Tegal Wangi. Fakta di lapangan menunjukkan bahwa memang anggota di Desa Curug tahu pasti performa ketua, baik dalam organisasi maupun kehidupan keseharian. Kedekatan ketua dengan anggota diperlihatkan dari jumlah kunjungan dan materi pembicaraan yang dilakukan. Kedekatan antara ketua dan anggota yang terjalin didukung oleh jarak yang dekat antara rumah ketua organisasi dan para anggotanya.

Hasil berbeda ditunjukkan dari responden di Desa Tegal Wangi. Hanya sedikit yang mengetahui sosok dari pemimpin gerakan dan bagaimana performanya dalam kegiatan organisasi maupun kehidupan keseharian. Hanya para penggagas di Desa Tegal Wangi yang mengenal baik sosok ketua karena seringnya kebersamaan dalam proses advokasi ke beberapa lembaga. Lebih jauh, responden lain mengaku hanya sebatas tahu dengan sosok ketua gerakan tetapi tidak kenal akrab mereka hanya mengetahui performa ketua gerakan dalam organisasi.

\section{Intensitas Kegiatan}

Kegiatan-kegiatan yang telah dilakukan oleh organisasi Forum Paguyuban Petani Jasinga dalam memperjuangkan kembali hak garap bagi masyarakat yakni proses pendampingan bagi masyarakat yang terkena proses hukum akibat kegiatan penggarapan yang pernah dilakukan, advokasi kepada DPRD Bogor dan LBH Jakarta, kebon 
forum, dan rapat internal.

\section{Tabel 11 Jumlah dan Persentase Responden Berdasarkan Intensitas Kegiatan}

\begin{tabular}{lll}
\hline Intensitas kegiatan & $\begin{array}{l}\text { J u m l a h } \\
\text { (orang) }\end{array}$ & $\begin{array}{l}\text { Persentase } \\
(\%)\end{array}$ \\
\hline Rendah & 22 & 44 \\
Sedang & 10 & 20 \\
Tinggi & 38 & 36 \\
Total & 50 & 100 \\
\hline
\end{tabular}

Struktur keanggotaan yang belum jelas menyebabkan orang yang terlibat dalam setiap kegiatan berbeda. Lebih jauh, untuk anggota paguyuban yang tingkat keaktifannya rendah menilai intensitas kegiatan rendah. Hal tersebut dikarenakan minimnya informasi terkait kegiatan organisasi yang diterima oleh responden tersebut. Selain itu, untuk kegiatan yang dilakukan di luar kota digunakan keterwakilan. Hal ini dikarenakan jarak tempuh yang jauh dan pendanaan yang minim membuat tidak memungkinkan untuk setiap anggota terlibat langsung. Pada setiap kegiatan yang dilakukan, tidak semua responden bisa hadir. Hal ini dikarenakan tidak ada tuntutan pada anggota paguyuban untuk hadir. Jika anggota paguyuban memiliki urusan lain, anggota paguyuban tersebut tidak hadir dalam kegiatan. Selain itu, informasi yang tidak menyebar rata menyebabkan anggota paguyuban tidak mengetahui pelaksanaan kegiatan.

\section{Tingkat Kolektifitas Aksi}

Tabel 12 Jumlah dan Persentase Responden Berdasarkan Tingkat Kolektifitas Aksi

\begin{tabular}{|c|c|c|c|}
\hline $\begin{array}{l}\text { Tingkat } \\
\text { aksi }\end{array}$ & kolektifitas & $\begin{array}{l}\mathrm{J} \text { u m } \mathrm{m} \text { a } \mathrm{h} \\
\text { (orang) }\end{array}$ & $\begin{array}{l}\text { Persentase } \\
(\%)\end{array}$ \\
\hline Rendah & & 15 & 30 \\
\hline Sedang & & 21 & 42 \\
\hline Tinggi & & 14 & 28 \\
\hline Total & & 50 & 100 \\
\hline
\end{tabular}

Tingkat kolektifitas aksi yang terkonsentrasi di tingkat sedang disebabkan oleh antar sesama anggota paguyuban (beda desa) hanya sedikit yang saling mengenal. Selain itu, keikutsertaan anggota paguyuban pada kegiatan organisasi jarang. Responden yang memiliki tingkat kolektifitas aksi tinggi adalah responden yang keikutsertaannya dalam kegiatan organisasi tinggi. Anggota paguyuban yang ada pada golongan ini adalah para penggagas organisasi. Keikutsertaan yang tinggi pada kegiatan organisasi disebabkan oleh para penggagas tersebut menjadi wakil organisasi dalam proses advokasi baik dalam maupun luar desa.

Di sisi lain, kebersamaan organisasi ini terlihat dari proses pengumpulan dana ketika harus melakukan pertemuan di luar desa. Setiap responden memberikan sumbangan seikhlasnya sebagai wujud bantuan ketika harus menghadiri pertemuan di luar desa.

Tingkat kolektifitas aksi yang ada pada Forum Paguyuban
Petani Jasinga belum tercermin dalam kehidupan keseharian. Hubungan yang terjalin masih sebatas hubungan organisasi. Selain itu, sebaran anggota paguyuban yang berada di dua desa menyulitkan proses interaksi antar setiap anggota. Interaksi dengan antar paguyuban hanya dilakukan dengan anggota paguyuban yang tinggal di desa yang sama sedangkan untuk interaksi antar anggota paguyuban di luar desa masih jarang. Hal tersebut dibuktikan dengan belum saling mengenalnya antar anggota paguyuban. Hanya para penggagas organisasi yang mengenal anggota paguyuban di luar desa mereka tinggal. Hal ini disebabkan oleh intensitas pertemuan pada kegiatan organisasi.

\section{Luas Jaringan Organisasi}

Lembaga yang membantu Forum Paguyuban Petani Jasinga dalam proses penyelesaian masalah sengketa lahan adalah LBH Jakarta, KomnasHAM, dan Ormas BPKB. Jenis bantuan yang diberikan berupa pendampingan, advokasi, dan mediasi.

\section{Tabel 13 Jumlah dan Persentase Responden} Berdasarkan Luas Jaringan Organisasi

\begin{tabular}{lll}
\hline $\begin{array}{l}\text { Luas jaringan organ- } \\
\text { isasi }\end{array}$ & $\begin{array}{l}\text { J u m l a h } \\
\text { (orang) }\end{array}$ & Persentase (\%) \\
\hline Rendah & 21 & 42 \\
Sedang & 17 & 34 \\
Tinggi & 12 & 24 \\
Total & 50 & 100 \\
\hline
\end{tabular}

Jumlah responden yang paling banyak ada pada kategori luas jaringan rendah. Hal ini disebabkan, responden yang jarang mengikuti kegiatan organisasi tidak tahu mengenai lembaga yang membantu dan bantuan yang diberikan oleh lembaga di luar organisasi. Anggota paguyuban yang tinggal di Desa Curug mengetahui lebih banyak jumlah lembaga yang membantu. Berbeda dengan anggota paguyuban yang tinggal di Desa Tegal Wangi yang sedikit mengetahui perihal bantuan yang diberikan oleh pihak luar. Hal ini disebabkan oleh, anggota paguyuban yang tinggal di Desa Curug menyadari keikutsertaanya dalam organisasi. Berbeda dengan anggota paguyuban di Desa Tegal Wangi yang tidak menyadari keikutsertaan dalam organisasi.

\section{Pengaruh Tingkat Terpenuhinya Dimensi Gerakan Petani terhadap Karakter Gerakan Petani}

Hasil uji statistik dengan menggunakan regresi berganda menunjukkan bahwa tingkat terpenuhinya dimensi gerakan petani memberikan pengaruh kepada setiap variabel dalam karakter gerakan petani. Hal tersebut dibuktikan dengan nilai $\mathrm{F}$ hitung yang lebih besar jika dibandingkan dengan $\mathrm{F}$ tabel dan nilai sig yang kurang dari 0.1. Berdasarkan aturan, jika kedua kondisi tersebut dipenuhi maka $\mathrm{H} 1$ diterima atau dengan kata lain menolak $\mathrm{HO}$.

- H0 : Diduga, terpenuhinya dimensi gerakan petani tidak berpengaruh terhadap karakter gerakan petani

- H1: Diduga, terpenuhinya dimensi gerakan petani berpengaruh terhadap karakter gerakan petani

Dimensi gerakan petani yang terkonsentrasi di level 
sedang memberikan pengaruh terhadap masing-masing variabel karakter gerakan petani. Dimensi gerakan petani yang dimiliki oleh setiap anggota paguyuban memberikan dampak pada karakter organisasi tani. Lebih jauh, hasil penelitian di lapangan menunjukkan bahwa menjadi satu hal yang berkesinambungan ketika unsur awal pada tahapan prakondisi pembentukan organisasi tidak dipenuhi dengan baik maka akan secara langsung mempengaruhi organisasi ketika sudah terbentuk.

Tabel 14 Hasil Uji Pengaruh Tingkat Terpenuhinya Dimensi Gerakan Petani terhadap Karakter Gerakan Organisasi Forum Paguyuban Petani Jasinga

\begin{tabular}{llll}
\hline Variabel & F tabel & F hitung & sig \\
\hline Efektivitas kepemimpinan & 2.894 & 12.359 & 0.001 \\
Intensitas kegiatan & 2.894 & 12.046 & 0.001 \\
Tingkat Kolektifitas Aksi & 2.894 & 27.289 & 0.000 \\
Luas jaringan & 2.894 & 28.423 & 0.000 \\
\hline
\end{tabular}

Terkonsentrasinya tingkat terpenuhinya dimensi gerakan petani pada tingkatan sedang membuat karakter dari organisasi Forum Paguyuban Petani Jasinga seperti saat ini. Berangkat dari kondisi dan kepentingan yang berbeda menyebabkan organisasi ini belum memiliki tingkat kolektiftas aksi yang tinggi. Hal ini dikarenakan intensitas hubungan antara dua desa ini sebagai satu unti organisasi masih minim. Selain itu, efektivitas kepemimpinan tidak seragam dikatakan tinggi. Hal ini dikarenakan responden di Desa Tegal wangi tidak mengenal baik pemimpin seperti responden Desa Curug. Di sisi lain, intensitas kegiatan dirasa kurang oleh responden di kedua desa. Hal ini dikarenakan setiapa responden tidak selalu ikut langsung dalam kegiatan sehingga tidak mengetahui perkembangan terkait kegiatan organisasi.

\section{SIMPULAN DAN REKOMENDASI}

Berdasarkan hasil analisis di atas, terdapat beberapa simpulan yaitu: (1) Perpanjangan Hak Guna Usaha di atas tanah seluas 938 hektar di Blok Cikidung pada tahun 2008 menyebabkan masyarakat kehilangan lahan garapan. Penebangan paksa terhadap tanaman milik masyarakat dilakukan oleh pihak perusahaan berdampak pada kerugian yang dialami oleh masyarakat. Perubahan struktur agraria lokal berupa hilangnya akses terhadap lahan garapan menyebabkan perubahan sosial ekonomi yang dialami oleh anggota paguyuban. Pengurangan luas penguasaan dan penurunan tingkat pendapatan terjadi setelah hilangnya akses terhadap lahan garapan. Keterlibatan dalam organisasi Forum Paguyuban Petani Jasinga menjadi pengalaman pertama berorganisasi bagi banyak anggota paguyuban. (2) Perubahan status sosial ekonomi seperti perubahan luas penguasaan lahan, perubahan tingkat pendapatan dan pengalaman berkelompok tidak berpengaruh terhadap tingkat terpenuhinya dimensi gerakan petani. (3) Tingkat terpenuhinya dimensi gerakan petani berpengaruh terhadap masing-masing variabel pada karakter gerakan petani (efektivitas kepemimpinan, luas jaringan, tingkat kolektifitas aksi, dan intensitas kegiatan). Tingkat terpenuhinya dimensi gerakan petani yang berbeda pada setiap anggota paguyuban memberikan pengaruh terhadap efektivitas kepemimpinan organisasi. Efektivitas kepemimpinan organisasi belum maksimal untuk seluruh anggota paguyuban di dua desa. Luas jaringan organisasi masih rendah karena sedikit dari anggota paguyuban yang mengetahui perkembangan organisasi. Intensitas kegiatan organisasi masih rendah karena tingkat kolektifitas aksi anggota paguyuban dalam organisasi pun rendah.

Rekomendasi yang dapat diberikan berdasarkan hasil analisis di atas yaitu: (1) pemerintah terutama Badan Pertanahan Nasional, serta instansi-instansi terkait lainnya untuk menindaklanjuti dan menyelesaikan sampai tuntas kasus sengketa tanah antara pihak perusahaan dan masyarakat di Desa Curug dan Desa Tegal Wangi. Selain itu, pemerintah perlu melakukan koordinasi dengan pihak kecamatan, perusahaan maupun kabupaten terkait penyelesaian kasus sengketa lahan di dua desa ini. (2) upaya mengoptimalkan fungsi Organisasi Forum Paguyuban Petani Jasinga dapat dilakukan dengan mengakomodasi tujuan anggota paguyuban dan tujuan organisasi secara umum. Lebih lanjut, perlu dilakukan pembentukan serta pengukuhan atas struktur organisasi dan anggota agar dapat membentuk organisasi yang kuat. Selain itu, perlu dilakukan pembuatan agenda kegiatan organisasi agar lebih terorganisir dan mampu mempererat kolektifitas organisasi.

\section{DAFTAR PUSTAKA}

Basrowi, Juariyah S. 2010. Analisis kondisi sosial ekonomi dan tingkat pendidikan masyarakat Desa Srigading, Kecamatan Labuhan Maringgai, Kabupaten Lampung Timur, Jurnal Ekonomi dan Pendidikan. [Internet]. [dikutip tanggal 9 Maret 2014]. 7(1): 5882. Tersedia pada: http://journal.uny.ac.id/index. $\mathrm{php} / \mathrm{jep} /$ article/view/577/434

Chrysantini P. 2010. Berawal dari Tanah (Melihat ke dalam Aksi Pendudukan Tanah). Bandung (ID): Yayasan Akatiga

Fauzi N. 2005. Memahami gerakan-gerakan rakyat dunia ketiga. Yogyakarta (ID): INSIST Press

Firmansyah, Aritonnang E, Terome H, Bahari Syaiful, S Hari Nanang. 1999. Gerakan dan pertumbuhan organisasi petani di Indonesia studi kasus gerakan petani era 1980-an. Jakarta (ID): YAPPIKA SEKRETARIAT BINA DESA

Hafidz JOS. 2001. Perlawanan petani kasus tanah Jenggaawah. Bogor (ID): Pustaka Latin

Hartoyo. 2010. Involusi gerakan petani dan nasib petani [disertasi]. Bogor (ID): Institut Pertanian Bogor. [Internet].[Diunduh 14 Desember 2013]. Tersedia pada: http://repository.ipb.ac.id/bitstream/ handle/123456789/55023/2010har.pdf?sequence=

Kammarudin SA. 2012. Pemberontakan petani Unra 1943. J Makara Sosial Humaniora.[Internet]. [Dikutip 10 Oktober 2013].16 (1). Tersedia pada: http://journal.ui.ac.idindex.php/humanities/article/ view/1222/1127

Landsberger HA, Alexandrov YG. 1974. Pergolakan petani dan perubahan sosial (Alih bahasa oleh Aswab Mahasin). Jakarta (ID): Rajawali Pers. 138 hal. 
Lestarini W. 2007. Pengaruh status sosial ekonomi terhadap pemilihan moda transportasi untuk perjalanan kerja (studi kasus karyawan PT. SSSWI Kabupaten Wonosobo). [tesis]. [internet]. [dikutip tanggal 9 Maret 2014]. Semarang (ID): Universitas Diponogoro. 108 hal. Tersedia pada: http://eprints. undip.ac.id/17736/1/Wiji_Lestarini.pdf

Mustapit. 2011. Perubahan struktur agraria dan harmoni semu [tesis]. Bogor (ID): Institut Pertanian Bogor

Novelisa A. 2012. Pengaruh reforma agraria terhadap perubahan struktur agraria di pedesaan (kasus redistribusi tanah di Desa Curug, Kecamatan Jasinga, Kabupaten Bogor, Provinsi Jawa Barat) [skripsi]. Bogor (ID): Institut Pertanian Bogor

Purwandari H. 2006. Perlawanan tersamar organisasi petani [tesis]. Bogor (ID): Institut Pertanian Bogor. [Internet].[Diunduh 23 Oktober 2013]. Tersedia pada: http://repository.ipb.ac.id/bitstream/ handle/123456789/9424/2006hpu.pdf

Scott J C. 1993. Perlawanan kaum tani. Jakarta (ID). Yayasan Obor Indonesia

Sihaloho M, Dharmawan AH, Rusli S. 2007. Konversi lahan dan perubahan struktur agraria. Sodality.01(01). [Internet]. [Diunduh 18 November 2013]. Tersedia pada: http://journal.ipb.ac.id/index.php/sodality

Sihaloho M, Purwandari H, Supriyadi A. 2008. Reforma agraria di bidang pertanian: studi kasus perubahan struktur agraria dan diferensiasi kesejahteran. Sodality.03(01). [Internet]. [Diunduh 10 November 2013]. Tersedia pada: http://journal.ipb.ac.id/index. php/sodality

Suhendar E. 1995. Ketimpangan penguasaan lahan di Jawa Barat. Bandung [ID]: Akatiga

Sitorus MTF, White B, Sumardjono MSW, Marzali A, Sayogyo, Husodo SW, Bahari S, Soetarto E, Agusta I, Nasution LI dkk. 2002. Menuju keadilan agraria. Bandung (ID). Akatiga

Sztompka P. 2011. Sosiologi perubahan sosial. Jakarta (ID). Prenada

[UU] Undang-Undang No. 5 Tahun 1960 tentang Peraturan Dasar Pokok-Pokok Agraria.[Internet]. [diunduh 12 Januari 2014]. Tersedia pada : http://dkn.or.id/ wp-content/uploads/2013/03/Undang-Undang-RInomor-5-Tahun-1960-tentang-Pokok-Pokok-DasarAgraria.pdf.

Wahyudi . 2009. Formasi dan struktur gerakan sosial petani (studi kasus gerakan reklaiming/penjarahan atas tanah PTPN X XII (Persero) Kalibakar Malang Selatan. J Salam.[Internet].[Diunduh 10 Oktober 2013]. Tersedia pada: http://ejournal.umm.ac.id/ index.php/salam/article/viewFile/436/443 umm scientific_journal.pd

White B dan Wiradi G. 2009. Reforma agraria dalam tinjauan komparatif: hasil lokakarya kebijakan reforma agraria di Selabintana. (Alih bahasa dari bahasa Inggris oleh Stephanus Aswar Herwinko). Bogor (ID): Brighten Press. 144 hal. [Judul asli Agrarian Reform in Comparative Perspective: Policy Issues and Research Needs]

Wiradi G. 2009. Seluk beluk masalah agraria, reforma agraria, dan penelitian agraria. Yogyakarta (ID): STPN Press

Yulisanti A. 2000. Status sosial ekonomi dan perilaku konsumtif kelas menengah baru. Yogyakarta (ID): APMD

Yunike R. 2012. Gerakan sosial politik omah tani di Kabupaten Batang. Politik Muda. [Internet]. [Diunduh 10 Oktober 2013]. Tersedia pada: http://journal.unair.ac.id/detail jurnal. php?id $=4240 \&$ med $=80 \&$ bid $=8$

Zuber, Ahmad. 2007. Pendekatan dalam memahami perubahan agraria di pedesaan. [Internet].[Diunduh 19 Desember 2013].Tersedia pada http://ahmad. zuber70.googlepages.com 